References

Hay PE. The diagnosis and management of vaginal discharge. In: Barton SE, Hay PE (eds), Handbook of Genitourinary Medicine. London, UK: Arnold, 1999; 83-95.

2 Department of Health. The National Strategy for Sexual Health and HIV. London, UK: Department of Health, 2001.

3 Scottish Executive. Enhancing Sexual Wellbeing in Scotland: A Sexual Health and Relationships Strategy. Edinburgh, UK: Scottish Executive, 2003 .

4 Andrews H, Acheson N, Huengsberg M, Radcliffe KW. The role of microscopy in the diagnosis of sexually transmitted infections in women. Genitourin Med 1994; 70: 118-120.

5 Stedman Y, Elstein M. Rethinking sexual health clinics. BMJ 1995 310: 342-343.

6 Laughlin S, Nandwani R, Ilett R, Bigrigg A. The Sandyford Initiative: creating added value to health and health care. Health Bull 2001; 59: $238-243$.

7 Wilkinson C, Hampton N, Bradbeer C. The integration of family planning and genitourinary medicine services. Br J Fam Plann 2000; 26: $187-188$

8 Dawson SGM, Callander NM, Roche CB, Kingsland TR, Desmond NM. Integrated sexual healthcare: the development and review of one model of service delivery. Int J STD AIDS 2000; 11: 428-434.

9 Jones M. Integrating family planning with genitourinary medicine: developing an holistic sexual health clinic in Eastbourne. Br J Fam Plann 2000; 26: 221-224.

10 Robinson J, Rogstad K. Modernisation of GUM/HIV services: what does it mean? Int J STD AIDS 2003; 14: 89-98.

11 Melville C, Nandwani R, Bigrigg A. Impact of the Sexually Transmitted Infections Foundation Course on the knowledge of family planning nurses and doctors (Letter). Sex Transm Infect 2003 ; family plann 346 .

12 Knottnerus JA, Weel V, Muris JWM. Evaluation of diagnostic procedures. BMJ 2002; 324: 477-480.

13 Rowen D. Streptococci and the genital tract. Int J STD AIDS 1993; 4: 63-66.

14 Sonnex C, Lefort W. Microscopic features of vaginal candidiasis and their relation to symptomatology. Sex Transm Infect 1999; 75: 417-419.

15 Melville C, Bigrigg A, Nandwani R. Client perspectives on sexual health service provision. Int J STD AIDS 2004; 15: 380-383.

16 Carne CA, Foley D, Kell P, Maw R. Variation in clinical practice in genitourinary medicine clinics in the United Kingdom. Sex Transm Infect 2003; 79: 240-242.

\title{
DR KATHARINA DALTON MEMORIAL SERVICE
}

A celebration of the life and works of Dr Katharina (Kittie) Dalton will take place at Rosslyn Hill Unitarian Chapel, Willoughby Road, Hampstead, London NW3 1SB on Saturday 22nd January 2005 at 2.00 pm.

All are welcome to share in the celebration and join Katharina's family and friends for refreshments afterwards. If you wish a particular item to be included in the service please contact Katharina's daughter, Wendy Holton. Tel: 01432 760993.E-mail: Holton@morlugg.freeserve.co.uk or m.dalton@btinternet.com.

\section{But is she positive?}

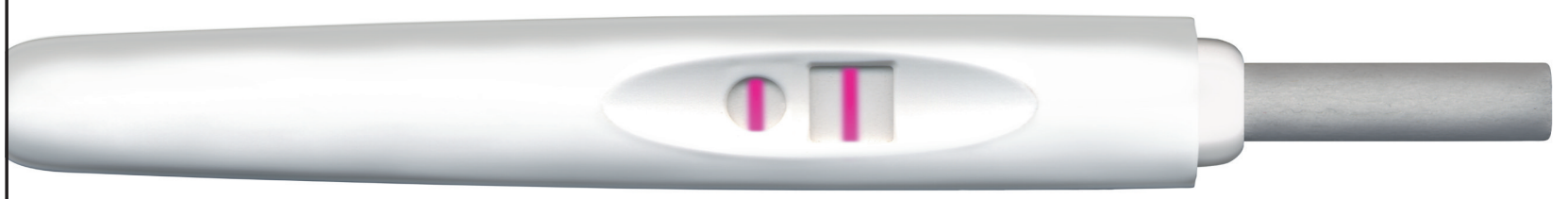

Your next patient is pregnant but doesn't want to be.

Where next? As a registered charity since 1968, bpas has offered affordable abortion care for women. We provide almost 50,000 abortions a year (including service agreements) and can offer all the professional help your patient needs.

bpas has a nationwide network of clinics and consultation centres. There are no long waits for appointments. We can offer a choice of times, clinics and procedures. All it takes to arrange an appointment is one call to the bpas Actionline on 08457304030.

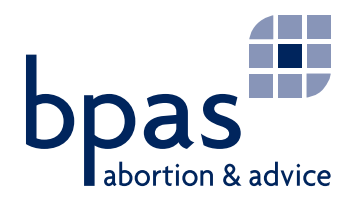

ACTIONLINE 08457304030 bpas positively the best service 